\title{
Ability of Students to Identify Intrinsic Elements in Short Stories from SMA Kesatrian 2 Semarang Students Through Problem-solving
}

\author{
Susi Sumarni ${ }^{1 *}$, Yessi Fitriani ${ }^{2}$, Darwin Effendi ${ }^{2}$ \\ ${ }^{1}$ SMA Negeri 6 Palembang \\ ${ }^{2}$ Universitas PGRI Palembang \\ *Corresponding author. Email: susisumarni304@gmail.com
}

\begin{abstract}
This study aims to describe the ability to identify intrinsic elements in collecting short stories by students of SMA Kesatrian 2 Semarang for SMA Negeri 6 Ogan Komering Ulu through problem-solving-learning. The method in this study used was action research, and the instruments used were observation and test. The research data analysis technique used a percentage. The results of the action in cycle one, the value obtained has not reached completeness. Then, after tracing the existing weaknesses, action-reflection is carried out in cycle one. Furthermore, in cycle two, it has increased, but has not indicated the expected completeness. After re-reflection in cycle two and followed up in cycle three, it was proven that the learning outcomes identified the intrinsic elements in collecting short stories by students of SMA Kesatrian 2 Semarang for SMA Negeri 6 Ogan Komering Ulu experienced good improvement using problem-solving and had reached the expected value determination.
\end{abstract}

Keywords: Short Stories, Problem-solving Learning, Intrinsic Elements

\section{INTRODUCTION}

Literary work is a form of a person's ideas through views of the social environment around him using beautiful language. Literature exists as a result of the author's contemplation of existing phenomena. Literature as a work of fiction has more in-depth understanding, not just an imaginary story from the author, but a form of the author's creativity in exploring and processing the ideas in his mind. Over time, the existence of literature is increasingly accepted in society. This can be seen from the fact that many literary works have been circulating in society.

A short story comes from two words, namely a story which means a story about how something happened and relatively short means a short story or no more than 10,000 words which gives a dominant impression and focuses only on one character in the short story [1]. In addition, short stories have a story length of about 5000 words or approximately 17 pages of double-spaced spaces that are centered and complete in themselves [2]. Furthermore, Priyatni [3] states that short stories are a form of fiction. The short story As the name implies, the short story shows a short nature, both the events that are revealed, the contents of the story, the number of actors, and the number of words used.
This comparison is associated with other forms of prose, such as novels. Short stories contain moral messages in the story's intrinsic elements with a number of words, not more than 10,000 words.

In short story learning activities, students are not only directed to understand theory such as recognizing short story features and the intrinsic elements of short stories, but short story learning is also directed at how students are able to analyze the intrinsic elements contained in short stories such as plot, background, point of view, themes, mandate, language style, character and others [4]. This means that learning literature in general and specifically expects students to understand theory and not ignore practice and application.

Based on the results of preliminary observations of Bahasa Indonesia learning obtained from the results of students' tests in the learning process to identify the life values contained in a collection of short stories, students were only able to obtain an average value of 63 . While the expected value was 75 . Students who achieved completeness of learning 16 students $(45.71 \%)$ of the 35 total students, while 19 students $(54.28 \%)$ students have not reached mastery learning. 
In this study, problem-solving learning is more relevant to life, especially in the world of work. The teaching and learning process through problemsolving can familiarize students with facing and solving problems skillfully. This is a significant ability for life. Problem-solving learning models can stimulate the development of students' thinking skills creatively and thoroughly. In the learning process, students carry out many coherent processes by highlighting problems from various aspects to achieve solutions [5].

Learning is a series of deliberately created activities with the intention of facilitating the learning process [6]. The teaching and learning process's learning model is the teacher's way or pattern of delivering lessons to students using learning methods, such as assignments, experiments, projects, inquiry, discussion, cooperation, or investigation [7]. The problem solving learning model is based on the belief in the fact that learning is not only conducting lectures and communicating with each other and one-way transfer of knowledge to students. But learning is also a step for investigating, analyzing, researching and thinking independently to find solutions to problems [8]. Problem solving model Problem Solving is a way of presenting lessons by encouraging students to look for and solve a problem or problem in order to achieve teaching goals [9].

The researcher conducted a search on the results of previous research, while the research that had been carried out related to this research included research conducted by Andriani [10] with the title of increasing the ability to analyze the intrinsic elements of short stories with the inside outside circle model of class XI IPA2 class students of SMA Negeri 1 Polewali Regency. Polewali Mandar. The result of this research is that the inside outside circle model can improve the ability to analyze the intrinsic elements of short stories from class XI IPA2 students of SMA Negeri 1 Polewali, Polewali Mandar Regency. Research conducted by Andriani [10] can be said to have similarities and differences with current research, namely both researching short story analysis. The difference is that Andriani [10] conducted research in class XI IPA2 of SMA Negeri 1 Polewali, Polewali Mandar Regency, while the current research conducted research in class XI IPA3 SMA Negeri 6 OKU.

Previous study was conducted by Fadma [11], with the title the ability to analyze the intrinsic elements of short stories for class X SMA Negeri 1 Bajeng, Gowa Regency. The results of his research show that the ability to analyze the intrinsic elements of the short story "Tak Bisa Pulang" for class X SMA Negeri 1 Bajeng, Gowa Regency is inadequate and the level of ability to analyze the intrinsic elements of the short story "Tak Bisa Pulang" is for class X SMA Negeri 1 Bajeng Kabupaten Gowa
Bajeng, Gowa Regency is categorized as low. Research conducted by Fadma [11] can be said to have similarities and differences with current research, namely both researching short stories. The difference is that Padma [11] conducted research in class X SMA Negeri 1 Bajeng, while the current research conducted research in class XI.

Effendi [12] also carried out another search, entitled The Author's Worldview in the Novel, The Moon Split in the American Sky, by Hanum Salsabiela Rais and Rangga Almahendra and Its Implications in Teaching Literature. This research shows that the author's world view represents their belief group, which is disturbed by the negative views of other groups that are not the same as their beliefs. The depiction of life in American social society through stories has inspired authors to convey Islam to those who do not understand it properly. As a Muslim, they are obliged to defend the truth of Islam which has been misunderstood. The author's world view also emphasizes that due to terrorist acts in the name of Islam, non-Muslim communities criticize and always blame Muslims. Research conducted by Effendi [12] can be said to have similarities and differences with current research, namely both researching literature teaching. The difference is that the current research examines a collection of short stories created by students of XI IPA-3 SMA Negeri 6 Ogan Komering Ulu.

\section{METHODS}

The research method used in this research is action research for class XI IPA-3 students at SMA Negeri 6 OKU. The data collection techniques used were observation and tests. Techniques are ways that researchers can collect data [13]. Observation is the observation of an object under study either directly or indirectly to obtain data that must be collected in research [14]. Arikunto [15] further argues that observation is a technique that is carried out by making careful observations and recording systematically.

Observation is to observe the students during problem-solving learning in the classroom. The test in this study was given in each cycle of 20 questions in the form of multiple choices, both the first cycle and the next cycle. The test was used to determine the increase in the ability of class XI students in identifying intrinsic elements in a collection of short stories by students of SMA Kesatrian 2 Semarang through a problem-solving learning model. The results of the learning process are guided by the expected value with reference to the percentage increase in each cycle.

The observation sheet in this study consisted of three observed indicators, including; The first is to be actively involved, meaning that the 
student's learning activities listen seriously to the given subject matter, students actively answer questions properly and correctly regarding the given learning material. Second is passive involvement, meaning that passive student learning activities listen seriously, passive students answer questions given by the teacher in the learning process and simple answer. Third is not involved, meaning that student learning activities are less active, and students just sit and stay still, student learning activities are not available, and students do not listen to the material presented by the teacher. Students are not active to ask or answer questions from the teacher.

\section{RESULTS AND DISCUSSION}

Cycle 1

Based on the results of the achievement of the test results of the ability to identify intrinsic elements in a collection of short stories created by students of SMA Kesatrian 2 Semarang through the problem solving learning model in class XI IPA-3 students at SMA Negeri 6 OKU cycle 1, the average score was 69.31. There were 21 students who achieved mastery based on the stipulated value limit of $>75$ or the average percentage of completeness was $58.33 \%$.

Based on the findings of cycle 1 action, the factors that affect the failure of students' learning completeness are due to: (1) describing activities, (2) explaining, or examining the elements that make up a short story, (3) the intrinsic elements that exist in a collection of short stories entitled: Pergi yang Kusesali karya Marini Alya Sary dan Pilu by Amalia Andhani, as a student at SMA Kesatrian 2 Semarang, (4) plot, (5) characterization, (6) background on a short story. This means that in the learning process identifying intrinsic elements in a collection of short stories by students of SMA Kesatrian 2 Semarang through a problem solving learning model in class XI IPA-3 students at SMA Negeri 6 OKU in cycle 1 have not yet reached learning completeness. Thus, researchers will continue to improve this learning in the next cycle, namely in cycle 2 , and it is hoped that in cycle 2 this can further increase student learning activities, especially the increase in identifying intrinsic elements in a collection of short stories by students of SMA Kesatrian 2 Semarang through the problem solving learning model in class XI IPA-3 at SMA Negeri 6 OKU.The findings of this study were an increase in students' ability to identify intrinsic elements in a collection of short stories by students of SMA Kesatrian 2 Semarang through a problemsolving learning model for class XI IPA-3 students at SMA Negeri 6 OKU. The learning process that is delivered shows an increase in student learning activity. This shows that there is a positive and very good increase. The test results used multiple-choice questions to identify the intrinsic elements in collecting short stories by students of SMA Kesatrian 2 Semarang through a problem-solving learning model in class XI IPA-3 students SMA Negeri 6 OKU have reached the set value.

Cycle 2

The main activity carried out by students in cycle 2 was to improve identifying intrinsic elements in a collection of short stories by students of SMA Kesatrian 2 Semarang through problem solving learning models in class XI IPA-3 students at SMA Negeri $6 \mathrm{OKU}$ in cycle 1. This revision learning took place. for $2 \times 45$ minutes. The activity was preceded by giving an apperception of the objectives to be achieved in learning to identify intrinsic elements in a collection of short stories by students of SMA Kesatrian 2 Semarang through a problem solving learning model for class XI IPA-3 students at SMA Negeri 6 OKU with the subject matter as follows: (1 ) Rindu ini Untukmu by Devi Yola Kurnia and Pemetik Mimpi by Michelle Asmaralda Venus, as a student of SMA Kesatrian 2 Semarang, as an effort to motivate students. After that, the learning process is carried out by focusing on the problem solving learning model that is conveyed in learning activities to identify the intrinsic elements in a collection of short stories by students of SMA Kesatrian 2 Semarang on the material: (1) Rindu ini Untukmu by Devi Yola Kurnia and Pemetik Mimpi by Michelle Asmaralda Venus.

Based on the results of the test data scores to identify intrinsic elements in a collection of short stories by students of SMA Kesatrian 2 Semarang through a problem solving learning model in class XI IPA-3 students at SMA Negeri 6 OKU cycle 2, it is known that students in the learning process have not yet reached completeness. Analysis of test data identifies intrinsic elements in a collection of short stories by students of SMA Kesatrian 2 Semarang through a problem solving learning model in class XI IPA-3 students at SMA Negeri 6 OKU cycle 2, it is known that 2645 with an average of 73.47 . Students who achieved mastery learning based on KKM> 75 were 28 students or an average percentage of completeness was $77.78 \%$. Thus, it can be said that in the action cycle 2 students' completeness in increasing the identification of intrinsic elements in a collection of short stories by students of SMA Kesatrian 2 Semarang through a problem solving learning model in class XI IPA-3 students at SMA Negeri 6 OKU has not been achieved, so Researchers need to do a review to do reflection and then take action in cycle 3 .

Cycle 3

Before implementation of the learning in cycle 3 , the researcher first gave apperception and 
focused on learning activities to identify intrinsic elements in a collection of short stories by students of SMA Kesatrian 2 Semarang on the material of Masa Depanku di Tangan Papa by Brigita Feonit Nerishi and Monster Mom VS Wonder Mom by Maydyana Ekstri Ayu Andani through problem solving learning model in class XI IPA-3 at SMA Negeri 6 OKU.

Based on the analysis of test data identifying intrinsic elements in a collection of short stories by students of Kesatrian 2 Semarang high school through the problem solving learning model in class XI IPA-3 students at SMA Negeri 6 OKU in cycle 3 , it is known that the results obtained by students are 2725 or 75,69 , students who achieved mastery learning $(\mathrm{KKM}>75)$ were 32 students or $88.88 \%$. Thus, it can be said that the increase in identifying intrinsic elements in a collection of short stories by students of SMA Kesatrian 2 Semarang through a problem solving learning model in class XI IPA-3 students at SMA Negeri 6 OKU in cycle 3 has reached the specified completeness.

\section{CONCLUSION}

Based on the results of action research findings, it can be concluded that there is an increase in identifying intrinsic elements in a collection of short stories by students of SMA Kesatrian 2 Semarang through problem-solving learning models in class XI IPA-3 students at SMA Negeri 6 OKU.

\section{REFERENCES}

[1] Susanto. (2011). Catatan Kecil tentang Menulis Cerpen. Yogyakarta: Pustaka Pelajar.

[2] Tarigan, H. G. (2012). Menulis Sebagai Suatu Keterampilan Berbahasa. Bandung: Angkasa.

[3] Priyatni. (2010). Berkenalan dengan Prosa Fiksi. Yogyakarta: Gama Media.

[4] Sudjiman. (2016). Mengenal Sastra Indonesia. Jakarta: Rajawali Pers.

[5] Djamarah, S. B. (2016). Strategi Belajar Mengajar. Jakarta: Rhineka Cipta.

[6] Pribadi, B. A. (2015). Model Desain Sistem Pembelajaran. Jakarta: Dian Rakyat.

[7] Hendy. (2016). Penerapan Pembelajaran yang Inovatif. Jakarta: Dian Pustaka.

[8] Hidayati. (2016). Model-Model Pembelajaran. Jakarta: Raja Grafindo Persada.

[9] Thobroni. (2011). Pemecahan Masalah dalam Proses Pembelajaran. Jakarta: Rineka Cipta.

[10] Andriani. (2016). Peningkatan Kemampuan Menganalisis Unsur Intrinsik Cerpen Dengan
Model Inside Outside Circle Siswa Kelas XI IPA2 SMA Negeri 1 Polewali Kabupaten Polewali Mandar. Jurnal Pepatuzdu, Volume 11 Nomor 1, Mei 2016. Halaman. 405-419. http://jurnal.bastra-andriani.co.id (Diakses pada 27 Agustus 2020).

[11] Padma. (2014). Kemampuan Menganalisis Unsur-Unsur Instrinsik Cerpen Siswa Kelas X SMA Negeri 1 Bajang Kabupaten Gowa. Jurnal Bastra, Volume 2 Nomor 3, Oktober 2014. Halaman 188-203. http://jurnal.bastrapadma.com (Diakses pada 27 Agustus 2020).

[12] Effendi, D. (2019). Pandangan Dunia Pengarang dalam Novel Bulan Terbelah di Langit Amerika Karya Hanum Salsabiela Rais dan Rangga Almahendra serta Implikasinya dalam Pengajaran Sastra. Jurnal Diksa: Pendidikan Bahasa dan Sastra Indonesia Vol. 5 No. 2, 2019.

[13] Anwar. (2014). Prosedur Penelitian Kualitatif dan Kuantitatif. Jakarta: Raja Graffindo Persada.

[14] Satori. (2016). Metode Penelitian Kualitatif. Jakarta: Rineka Cipta.

[15] Arikunto, S. (2010). Prosedur Penelitian Suatu Pendekatan Praktek. Jakarta: Rineka Cipta. 